\title{
PATTERN OF OVARIAN NEOPLASM IN RURAL POPULATION: A FIVE YEAR STUDY FROM TERTIARY CARE HOSPITAL
}

\author{
Umesh Jindal ${ }^{1}$
}

\section{HOW TO CITE THIS ARTICLE:}

Umesh Jindal. "Pattern of Ovarian Neoplasm in Rural Population: A Five Year Study from Tertiary Care Hospital" Journal of Evolution of Medical and Dental Sciences 2014; Vol. 3, Issue 08, February 24;

Page: 2033-2039, DOI: 10.14260/jemds/2014/2099

ABSTRACT: OBJECTIVE: The aim of the study was to know the morphological pattern of benign and malignant ovarian neoplasms and their distribution in different age groups in rural population of India. MATERIAL AND METHODS: A retrospective study of all cases of ovarian neoplasms diagnosed at department of pathology, Maharaja Medical College, Agroha during period of five year (Aug, 07Oct.12) was done. The tumors were classified according to WHO classification after thorough examination of slides and their distribution in different age groups was also noted. RESULTS: There were total fifty three cases of ovarian tumors noted during this period. Benign tumors comprised 81.13\% and malignant tumors were 18.86\%. Surface epithelial tumor emerged as the commonest variety accounting for $60.37 \%$, followed by germ cell tumor (32.07\%) and sex cord stromal tumors were least common comprising $7.54 \%$ of all ovarian neoplasm. No metastatic tumor or tumors with borderline malignancy were seen. Serous cystadenoma was the commonest tumor (43.39\%) followed by mature cystic teratoma (30.23\%).Among the malignant tumor, malignant germ cell tumor were the commonest type (40\%), followed by $30 \%$ of each surface epithelial tumor and sex cord stromal tumor. CONCLUSION: Benign ovarian tumors are seen more common than malignant tumor. Malignant epithelial tumors are seen after the age of 30 years and malignant germ cell tumor are seen below the age of 30 years. Bilaterality is more commonly seen in malignant ovarian neoplasm.

KEYWORDS: ovarian tumors, surface epithelial tumors, germ cell tumors, sex cord stromal tumors, teratoma, and serous cystadenoma.

INTRODUCTION: Ovarian neoplasm is the most fascinating tumor of the women in term of its histogenesis, clinical behavior and malignant potentiality. Histogenesis of ovarian tumor includes a complex wide spectrum of neoplasm depending upon the origin of cell i.e. tumor arising from epithelial tissue, germ cell and connective tissue. ${ }^{1}$ As ovary is an intra-abdominal organ; clinical diagnosis of ovarian tumor is often late. So, ovarian tumors are notorious for their large size and frequent association with mild symptoms. ${ }^{2}$ Ovarian neoplasm can occur in all age groups and no age is exempted, however type of neoplasm usually varies with age.

Unlike cervical cancer, identification of high risk population for ovarian malignancy and ideal screening methods are not available. Risk factors for ovarian cancers are not well understood. However there is agreement on two, Nulliparity and family history. A higher frequency of carcinoma is seen in unmarried and in women with low parity. ${ }^{3}$

Ovarian carcinoma is the sixth commonest female cancer and fourth leading cause of death due to cancer in women. Asian countries and Japan have rates of 2-6.5 new cases per 10,000 women per year. Indian Cancer Registry data project ovary as an important site of cancer in women, comprising up to $8.7 \%$ of cancers in different parts of country. ${ }^{4}$ The recent Surveillance, Epidemiology 
and End result (SEER) calculation of life time risk for ovarian cancer are that 1 in 55 women will develop ovarian cancer in their lifetime.

Determination of various histologic patterns of ovarian tumors is very important in diagnosis as well as prognosis of these tumors. Prognosis of the tumors can also be predicted from the degree of differentiation of the tumors. Also the laterality of tumor also indicates their nature. The aim of this study was to know the incidence and histopathological spectrum of ovarian tumors which are more prevalent in our rural population.

MATERIALS AND METHODS: It is a retrospective study of all the cases of ovarian tumors operated in maharaja Agrasen Medical College and Hospital from august, 2007 to October, 2012 and sent for histopathological examination in department of pathology.

Only the spectrums of ovarian tumors are considered in this study. The normal ovaries and ovaries with other nonspecific findings like follicular cyst, cystic follicle, surface inclusion cyst, corpus luteal hemorrhagic cyst were excluded from the study.

All the excised specimen of ovaries was fixed in 10\% formalin. From cyst, upto 3 sections were taken from cyst wall of smooth wall cyst. If wall show papillary projections or solid areas extra sections were taken depending upon size. For solid tumors, one section for each centimeter was taken depending upon need. One section of non-neoplastic ovary was taken where it was identifiable.

After sectioning, tissues were processed in an automated tissue processor. An overnight schedule of 16-18 hrs. was used. After processing, paraffin block was made. The tissue section of same were cut and stained by H\& E. The stain were cleared by xylene and mounted and slides examined under light microscope. The histopathological diagnosis was made on detailed morphological features and tumors were classified according to WHO classification. Then analysis was done to find out the incidence and various subtypes of ovarian tumors.

OBSERVATIONS AND RESULTS: There were total 53 specimens of ovarian tumor obtained for histopathological examination during period of august, 2007 to October, 2012.

Ovarian tumors were categorized mainly into three groups. Surface epithelial tumor constitute majority of ovarian neoplasm with a incidence of $60.37 \%$, followed by Germ cell tumor which comprised $32.07 \%$ and Sex cord stromal tumor were least common and constitutes 4 cases with a percentage of $7.54 \%$. Out of total 53 cases, 43 cases were of benign nature and comprised $81.13 \%$ of all neoplasm. Ten cases belong to malignant category with a percentage of $18.86 \%$. (Table1).

Among the benign tumors, 56.60\% tumors were seen below the age of 40 years. Most common benign tumor observed was serous cyst adenoma with percentage of $43.39 \%$ among all benign tumors and distributed mainly in third decade (47.86\%). Next common benign tumor seen was mature cystic teratoma with a percentage of $30.23 \%$ and seen through second decade to sixth decade. Other benign tumors observed were three cases of papillary serous cystadenofibroma (6.97\%), three cases of mucinous cystadenoma (6.97\%) and a case of benign sertoli leydig cell tumor (2.32\%) (Table-2).

Germ cell tumors were the most common observed malignant group with a percentage of $40 \%$.All the malignant germ cell tumor were seen below the age of 30 years. We observed one case 


\section{ORIGINAL ARTICLE}

each of Immature Teratoma, Mixed Germ cell tumor, Dysgerminoma and Embryonal carcinoma. Surface epithelial tumors and sex cord stromal tumors comprises 30\% each in malignant spectrum of ovarian neoplasm. Among the surface epithelial tumor there was one case each of endometroid carcinoma, serous adenocarcinoma and poorly differentiated mucinous adenocarcinoma. There were two cases of Adult Granulosa tumor and one case of juvenile Granulosa tumor among sex cord stromal tumors. All the epithelial malignant tumors were seen after the third decade and sex cord stromal tumors were seen between the second to sixth decades. (Table-3).

Gross examination of all ovarian tumors revealed that benign tumors were mainly of cystic type with occasional small papillary projections and size was between $4 \mathrm{X} 2 \mathrm{cms}$ to $30 \mathrm{X} 10 \mathrm{cms}$.Benign cystic teratoma ranged in size from $5 \times 5 \mathrm{cms}$ to $18 \mathrm{X} 14 \mathrm{cms}$ and on cut surface shows sebum like material with hair in it. Malignant tumor showed heterogeneous proportion of solid and cystic component with size range from $11 \times 7 \mathrm{cms}$ to $22 \times 15 \mathrm{cms}$. (Table-4).

Bilateral ovarian tumors were seen in four patients comprising $07.54 \%$ of all ovarian neoplasms. Bilaterality was more a feature of malignant tumors as $30 \%$ malignant tumors were bilateral where only $2 \%$ benign tumor was bilateral.

DISCUSSION: Ovarian tumors are one of major health problems confronting the gynecological practitioner in OPD. Ovarian tumor may be either totally asymptomatic or may be found on routine ultrasound examination. Sometimes symptoms may be vague that patient actually present with an acute emergency like torsion of cyst. But the worst is late presentation of ovarian tumor. It is generally impossible to diagnose the nature of neoplasm preoperatively just by doing clinical examination. Hence, one has to depend upon pathological findings for classification and further management of ovarian neoplasm. As our college is situated in a village, most of our patients have low education level and low socioeconomic status, so in many cases presentation of ovarian tumor in often late.

A total of 53 cases were observed during this study, out of which benign tumor comprised 81.13\% and malignant tumor were $18.86 \%$.There was no tumor with borderline malignancy. These results are comparable to study carried out by Sumaira Yasmin et al ${ }^{5}$ where they found that out of total 68 tumors during study $89.7 \%$ tumors were benign and $10.29 \%$ tumors were malignant with no borderline malignancy. Similar findings were showed by R Jha et al 6 in their study in which they found that $83.9 \%$ tumors were benign and $16.7 \%$ were malignant out of total 161 ovarian tumors with no borderline malignancy. Also various studies carried out by different authors ${ }^{7-9}$ had similar observations regarding the incidence of malignant and benign tumors.

The commonest category of ovarian tumor encountered in our study was surface epithelial tumor $(60.37 \%)$, followed by germ cell tumor (32.07\%) and sex cord stromal tumor (7.54\%). Similar observations have been shown by various authors ${ }^{8,9}$ who had carried out the study on ovarian tumors in same southeast region. Also In a study carried out by Pilli et al ${ }^{7}$ in India they found that surface epithelial tumors were the commonest variety constituting $70.9 \%$ of all the ovarian tumors followed by germ cell tumors (21.2\%), sex cord stromal tumors (6.7\%) and metastatic tumors $(0.7 \%)$.

Serous tumor constituted the commonest tumor among surface epithelial tumor and comprised $75 \%$ of all epithelial tumors, an observation identical to other authors regarding ovarian 
neoplasm in India. ${ }^{10,11}$ Serous cystadenoma was the most common among the serous tumors in this study, an observational same to Maheshwari V et al.12 in study of Thaniskasalam et al ${ }^{13}$ in Malaysia, teratomas were commonest benign tumors among Malays and Chinese whereas serous cystadenoma was commonest among Indians. Majority of benign serous tumors occur in $4^{\text {th }}$ to $6^{\text {th }}$ decade although they may occur in patients younger than 20 or older than 80 years. ${ }^{14}$ Similar observations have been found in this study also. Among the rest benign epithelial tumors observed were three cases each of papillary cystadenofibroma and mucinous cystadenoma. All the malignant epithelial tumors were seen after $3^{\text {rd }}$ decade and comprised one case each of serous cystadenocarcinoma, endometrial carcinoma and poorly differentiated mucinous cystadenocarcinoma without predilection to any specific tumor.

We found that Germ cell tumor comprised 32.07\% of all ovarian neoplasm, an observation similar to Ahmad et al ${ }^{15}$ where they found the incidence of $27.13 \%$.Results are also comparable to findings of Sah et $\mathrm{al}^{16}$ and Kooning et $\mathrm{al}^{17}$ where they found slightly high incidence of $43 \%-44 \%$. Mature cystic teratoma was the commonest benign tumor $(76.4 \%)$ identical to observation made by Pradhan et al ${ }^{8}$. All the malignant germ cell tumors were seen below the age of 30 years. this finding corresponds to the published figures.18-20 Among the malignant tumors we observed a case of bilateral Dysgerminoma, case of mixed germ cell tumor, case of immature teratoma and a case of Embryonal carcinoma.

Sex cord stromal tumors represent approximately $8 \%$ of all ovarian neoplasm and were seen in all age groups, finding consistent with other studies. 5, 8 Granulosa cell tumor was the most common tumor (75\%) observed in this group with one case of sertoli leydig cell tumor.

There were $10 \%$ patients with bilateral tumors in this study out of which $70 \%$ tumors were malignant and 30\% were benign in nature indicating bilaterality is significant risk factor for malignancy, an observation identical to other studies. ${ }^{9}$

Thus we conclude that benign tumors are more common than malignant ones. Surface epithelial tumors are most common class of tumors. Considering individual tumor serous cystadenoma is most common ovarian tumor followed by mature cystic teratoma in our setup Malignant epithelial tumor are more common above the age of 40 years and malignant germ cell tumors were seen below the age of 40 years. Bilaterality is more frequently seen in malignant tumors.

\section{REFERENCES :}

1. Ellenson LH, Pirog EC. The Female Genital Tract. In: Robbins and Cotran Pathologic Basis of Disease, 8th ed. Saunders Elsevier, Philadelphia.2010:1005-1063.

2. Scully Robert E, Young Robert E, Clement Philip B. Atlas of Tumor Pathology. Tumors of the ovary, maldeveloped gonads, fallopian tube and broad ligament. $3^{\text {rd }}$ series, Fascicle 23 . Armed Force Institute of Pathology, 1999.

3. Rosai J .Ovary. In: Rosai and Ackerman's surgical pathology 10 $10^{\text {th }}$ Ed. Missouri: Elsevier; 2011.vol2.p.1553-1635.

4. Murthy NS, Shalini S, Suman G, Pruthvish S, Mathew A. Changing trends I incidence of ovarian cancer- the Indian scenario . Asian Pac J Cancer Prev 2009; 10:1025-30.

5. Yasmin S, Yasmin A, Asif M. Clinicohistological pattern of ovarian tumors in Peshwar region. J Ayub Med Coll Abbottabad 2008; 20(4):11-13. 
6. Jha S, Karki S. Histological pattern of ovarian tumors and their age distribution. Nepal Med Coll J 2008; 10(2):81-85.

7. Pilli GS, Suneeta KP, Dhaded AV, Yenni VV. Ovarian tumors: a study of 282 cases. J Indian Med Assoc 2002; 100:420-24.

8. Pradhan A, Sinha AK, Upreti D. Histopathological patterns of ovarian tumors at BPKIHS. Health Renaissance 2012; 10(2):87-97.

9. Kayastha S. Study of ovarian tumors in Nepal Medical College Teaching Hospital. Nepal Med Coll J 2009; 11(3):200-202.

10. Chhanda M, Dasgupta A, Ghosh RN, Sengupta J. ovarian tumors: a ten year study. Journal of obstetrics and Gynecology of India.; 1990 Dec: 691-5.

11. Sarkar R. Ovarian neoplasm: A 14 year study. Journal of obstetrics and Gynecology of India.; 1996 Nov: 156-9.

12. Maheshwari V, Tyagi SP, Saxena K, Tyagi N, Sharma R, Aziz M, Hameed F. Surface epithelial tumors of ovary. Indian J Pathol Microbiol 1994 Jan; 37(1):75-85.

13. Thanikasalam K, Ho CM, Adeed N, Shahidan N, Azizah WK. Pattern of ovarian tumors among Malaysian women at General Hospital, Kuala Lumpur. Med J Malaysia1992; 47:139-46.

14. Tavassoli FA, Devilee P. WHO Classification of tumors. Pathology and Genetics, Tumors of Breast and Female Genital Organs. IARC Press: Lyon 2008.

15. Ahmad Z, Kayani N, Hasan SH, Muzaffar S, Gill MS. Histological pattern of ovarian neoplasm. J Pak Med Assoc 2000; 50:416-419.

16. Sah SP, Uperty D, Rani S. Germ cell tumor of the ovary: a clinicopathologic study of 121 cases from Nepal. J Obestet Gynaecol Res 2004; 30:303-8.

17. Koonings PP, Campbell K, Mishell DR Jr, Grimes DA. Relative frequency of primary ovarian neoplasm: a 10 year review. Obstet Gynaecol1989; 74:921-26.

18. Bhattcharyya NK, De A, Bera P, Sristidhar M, Chakraboty S, Bandopadhyay R. Ovarian tumors in pediatric age group- A clinicopathologic study of 10 years cases in West Bengal, India. Indian J Med Paediatr Oncol 2010; 31(2):54-57.

19. Jadhav BJ, Shinde AM. Ovarian germ cell tumor: a 3 year study. J Obestet Gynecol India 2005; 55(1):61-63.

20. Choudry A, Bangash N, Malik A, Choudry H. Adolescent Ovarian Tumors: A Clinicopathological Review of 15 cases. J Ayub Med Coll Abbottabad 2008; 20(4):18-21.

\begin{tabular}{|c|l|c|c|c|}
\hline Sl no. & \multicolumn{1}{|c|}{ Type of Tumor } & Benign & Malignant & Total \\
\hline 1 & Surface epithelial tumor & 29 & 03 & 32 \\
\hline 2 & Germ cell tumor & 13 & 04 & 17 \\
\hline 3 & Sex cord stromal tumor & 01 & 03 & 04 \\
\hline 4 & Total & $\mathbf{4 3}$ & $\mathbf{1 0}$ & $\mathbf{5 3}$ \\
\hline
\end{tabular}

Table 1: Distribution of different types of benign and malignant tumor 
ORIGINAL ARTICLE

\begin{tabular}{|c|c|c|c|c|c|c|c|c|}
\hline \multirow{2}{*}{$\begin{array}{r}\text { Sl } \\
\text { no. }\end{array}$} & \multirow{2}{*}{$\begin{array}{l}\text { Type of Benign } \\
\text { tumor }\end{array}$} & \multicolumn{6}{|c|}{ Age groups } & \multirow[b]{2}{*}{ Total } \\
\hline & & $\begin{array}{c}<20 \\
\text { years }\end{array}$ & $\begin{array}{l}21-30 \\
\text { years }\end{array}$ & $\begin{array}{l}31-40 \\
\text { years }\end{array}$ & $\begin{array}{l}41-50 \\
\text { years }\end{array}$ & $\begin{array}{l}51-60 \\
\text { years }\end{array}$ & $\begin{array}{c}>60 \\
\text { years }\end{array}$ & \\
\hline 1 & $\begin{array}{l}\text { Mature cystic } \\
\text { teratoma }\end{array}$ & & 05 & 03 & 02 & 01 & 02 & 13 \\
\hline 2 & $\begin{array}{c}\text { Serous } \\
\text { Cystadenoma }\end{array}$ & 03 & 03 & 11 & 04 & 01 & 01 & 23 \\
\hline 3 & $\begin{array}{c}\text { Papillary } \\
\text { cystadenofibroma }\end{array}$ & & 02 & & & 01 & & 03 \\
\hline 4 & $\begin{array}{l}\text { Sertoli leydig } \\
\text { cell tumor }\end{array}$ & & 01 & & & & & 01 \\
\hline 5 & $\begin{array}{c}\text { Mucinous } \\
\text { cystadenoma }\end{array}$ & 03 & & & & & & 03 \\
\hline 6 & Total & 06 & 11 & 14 & 06 & 03 & 03 & 43 \\
\hline
\end{tabular}

\begin{tabular}{|c|c|c|c|c|c|c|c|c|}
\hline \multirow[b]{2}{*}{$\begin{array}{r}\text { Sl } \\
\text { no. }\end{array}$} & \multirow{2}{*}{$\begin{array}{c}\text { Type of } \\
\text { Malignant } \\
\text { tumor }\end{array}$} & \multicolumn{6}{|c|}{ Age groups } & \multirow[b]{2}{*}{ Total } \\
\hline & & $\begin{array}{c}<20 \\
\text { years }\end{array}$ & $\begin{array}{l}21-30 \\
\text { years }\end{array}$ & $\begin{array}{l}\text { 31-40 } \\
\text { years }\end{array}$ & $\begin{array}{l}41-50 \\
\text { years }\end{array}$ & $\begin{array}{l}51-60 \\
\text { years }\end{array}$ & $\begin{array}{c}>60 \\
\text { years }\end{array}$ & \\
\hline 1 & $\begin{array}{l}\text { Germ cell } \\
\text { tumor }\end{array}$ & 01 & 03 & & & & & 04 \\
\hline 2 & $\begin{array}{c}\text { Surface } \\
\text { Epithelial tumor }\end{array}$ & & & 01 & & & 02 & 03 \\
\hline 3 & $\begin{array}{l}\text { Sex cord stromal } \\
\text { tumor }\end{array}$ & 01 & & 01 & 01 & & & 03 \\
\hline 6 & Total & 02 & 03 & 02 & 01 & 00 & 02 & 10 \\
\hline
\end{tabular}

\begin{tabular}{|c|c|c|c|}
\hline Sl no. & Type of tumor & Gross Pathological feature & Size Range \\
\hline 1 & $\begin{array}{c}\text { Benign Epithelial } \\
\text { tumor }\end{array}$ & $\begin{array}{c}\text { 1. Predominantly cystic. } \\
\text { 2. Predominantly cystic with } \\
\text { small papillary projections }\end{array}$ & $2 \times 4 \mathrm{cms}-10 \times 30 \mathrm{cms}$ \\
\hline 2 & $\begin{array}{c}\text { Benign cystic } \\
\text { teratoma }\end{array}$ & $\begin{array}{c}\text { cystic with sebum like } \\
\text { material with hairs }\end{array}$ & $5 \times 5 \mathrm{cms}-14 \times 18 \mathrm{cms}$ \\
\hline 3 & $\begin{array}{c}\text { Malignant epithelial } \\
\text { tumor }\end{array}$ & $\begin{array}{c}\text { Variegated } \\
\text { (Solid +cystic) }\end{array}$ & $7 \times 11 \mathrm{cms}-15 \times 15 \mathrm{cms}$ \\
\hline 4 & $\begin{array}{c}\text { Malignant germ } \\
\text { cell tumor }\end{array}$ & $\begin{array}{c}\text { Variegated } \\
\text { Homogeneous solid }\end{array}$ & $9 \times 12 \mathrm{cms}-19 \times 20 \mathrm{cms}$ \\
\hline 5 & $\begin{array}{c}\text { Sex cord stromal } \\
\text { tumor }\end{array}$ & $\begin{array}{r}\text { Predominantly solid } \\
\text { or solid/cystic }\end{array}$ & $10 \times 13 \mathrm{cms}-15 \times 22 \mathrm{cms}$ \\
\hline \multicolumn{4}{|c|}{ Table. 4: Gross features of benign and malignant tumors } \\
\hline
\end{tabular}




\section{ORIGINAL ARTICLE}

\section{AUTHORS:}

1. Umesh Jindal

\section{PARTICULARS OF CONTRIBUTORS:}

1. Associated Professor, Department of Pathology, Maharaja Agrasen Medical College, Agroha, Hisar, Haryana, India.

\section{NAME ADDRESS EMAIL ID OF THE} CORRESPONDING AUTHOR:

Dr. Umesh Jindal, House No. 1088, Sector 14, Hisar, Haryana, India.

E-mail: drumeshhisar@yahoo.com

Date of Submission: 03/02/2014. Date of Peer Review: 04/02/2014. Date of Acceptance: 08/02/2014. Date of Publishing: 22/02/2014. 